\title{
Politeness Language Analysis in Teenagers Reviewed from Sociolinguistics
}

\author{
Muhammad Darwis \\ Postgraduate Student of Indonesian Language Education Study Program in University of Syiah Kuala \\ ahmadyuhdi@gmail.com
}

\begin{abstract}
This study aims to find out and describe data on language politeness among teenagers in Kuala Simpang city, Aceh Tamiang district in terms of sociolinguistics. The appropriate research approach uses in this study is qualitative research. The type of research is field research. The data of this study is the conversation of teenagers of Bukit Tempurung Village, Kuala Simpang City. Data sources are a number of teenagers in Bukit Tempurung Village, Kuala Simpang City. Data collected by recording techniques during social activities, then in manuscripts in the form of conversation. The results showe that there are 6 languages politeness maxims used by teenagers during social activities. Maksim is in the form of wisdom maxims of four (4) data, generosity maxims as much as seven (7) data, award maxims of two (2) data, simplicity maxim of one (1) data, consensus maximization of fourteen (14) data, and the implicit maxim of one (1) data. Based on the research data, the most dominant maxim is the agreement maxim.
\end{abstract}

Keywords: politeness of language; village of hillside village; sociolinguistics

\section{Introduction}

Humans as social beings cannot live alone without the presence of others. This makes it clear that basically humans are social beings. Humans interact with other people using communication tools. Communication tools use to ask questions, express themselves, and influence others for their own interests and mutual interests. Communication made by humans uses polite and easy to understand language. Courteous language will sound better and keep people's feelings from being offended.

Language plays an important role in human life. Humans use language as a means to communicate. Language is related to the principle of politeness of language which is mentioned the maxims of wisdom, generosity, appreciation, simplicity, consensus and conclusions. So from the six maxims the adolescent must use a lot of maxims which expedite the conversation, cooperate with each other in speaking and give mutual appreciation in speaking and at least the simplicity maxim is needed.

Based on observations we find among adolescents the principle of politeness in language has begun to fade when communicating. Researchers see that adolescents still often use the maxim of simplicity and at least adolescents use the principles of wisdom, generosity, appreciation, consensus, and conclusions. Of course this is not a good example of communication, when in the community both are doing social activities and non-social activities. Adolescents should multiply the principle of agreement in communication so that communication between friends becomes smooth and directed towards the goals to be conveyed. If the minimum agreement is used in communication, the result can shorten the conversation, be selfish, not please other people and appear arrogant in the conversation.

Based on the problems that occur in the village of Bukit Tempurung, Kuala Simpang, the dominant teenager uses the principle of simplicity in speaking. So that the communication of local teenagers is very short in speaking there is no reciprocity in communication. That is the researcher wants to increase knowledge to adolescents. Should speak in attention to the 
principle of politeness of language so that communication is interwoven smoothly. It is hoped that this research will increase knowledge in Pragmatics, especially politeness.

Language is the ability that humans have to communicate with other humans so that the existence of language can run good communication. Likewise with the opinion of Leonie Agustina (2004: 11) language is an arbitrary verbal symbol system that is used by members of a language community to communicate and interact between each other, based on the culture they have together. Saussure (Chaer 2004: 12) also argues, Language is the most prominent distinguishing feature because with language each social group feels itself to be a different entity from another group.

Then the language will not be separated from the politeness of the language that applies in society. Modesty shows attitude in daily interactions. A person can be said to be polite, if the principles of politeness are applied in the community. In addition, someone who is polite must adjust to the community, place, and situation he faces. In this case Erase 1990 (Rahardi 2005: 40) also argues that language politeness is a view of action to fulfill the requirements of a conversation contract. which is seen in a social index and many are in the form of social references, honorifics and speech styles. Then Lakoff 1972 (Ruhardi 2005: 41) also agreed with politeness language researchers that it could be said to be polite if polite speech both formal and non-formal, was not compelling and did not impress so proudly that the partner felt comfortable.

Sociolinguistics is an interdisciplinary science between sociology and linguistics, two fields of empirical science that have very close links, this science is applied in communicating with fellow humans. Collaborating in language, whether there are social activities or not in social activities. According to Appel, Hubert, Meijer 1976: 10 (Chaer, Agustina 2004: 4) also argues the same as socialolinguistic researchers is the study of language and its use in social and cultural contexts. Rafiek (Chaer, Agustina 2004: 23) defines sociolinguistics as a language study in its implementation that aims / aims to learn how conventions regarding the use of language relations for other aspects of social behavior. Then linguistics studies social factors that play a role in language association and social interaction. With the existence of these problems, the researcher conducted a study entitled "Analysis of politeness in the language of Kalang

\section{Research Methods}

This study used qualitative approach and the type of research was field research. The data in this study were adolescent conversations, Bukit Tempurung village, Kuala Simpang sub-district, Aceh Tamiang Regency when interacting with other people, while the data sources in the study were a number of teenagers, Bukit Tempurung village, Kuala Simpang sub-district, Aceh Tamiang Regency when researchers gathered data.

Data collection techniques used in research were through documentation. The steps:

1) Researchers visited youth associations in the form of discussions and social activities.

2) Researchers recorded conversations among adolescents when communicating with each other through communication media recorders.

3) The researcher played and listened to the recording.

4) The researcher retransmited adolescent conversations in the form of conversation dialogue. 
5) Researchers classified data based on the principle of politeness of language in the

6) conversation of adolescents when communicating with each other, then analyze and conclude.

\section{Results and Discussion}

After the researchers heard and read manuscripts among teenagers in Bukit Tempurung Village, Kuala Simpang Subdistrict, Aceh Tamiang Regency, on March 25, 2018 language politeness was found, Twenty-nine of these data were grouped into six maxims, namely: maxim wisdom, generosity, maxim of reward, maxim of simplicity, maxim of consensus and maxim of conclusions. The research data on language politeness is described as follows.

\subsection{Maxim Wisdom (Maxim Tact)}

\section{Data 1}

Ridho: Yes bang, just join us. (manuscript of mutual cooperation activities page 1 line 4).

\section{Data 2}

Ridho: Just come, sir. We'll wait for you. (manuscript of mutual cooperation activities page 3 line 54).

\section{Data 3}

Ridho: Alright, I'll come later. (manuscript of mutual cooperation activities page 4 line 60).

\section{Data 4}

Ridho: Waalaikumsalam. Come in, Wis. (manuscript for maulid activities page 1 line 2)

\subsection{Maksim Generosity}

\section{Data 5}

Rizki: Yes, just join us. (manuscript of mutual cooperation activities page 1 line 10).

\section{Data 6}

Ridho: If you want to know this person, we will sit in coffee shop where $\mathrm{i}$ work, if you don't mind? (manuscript of mutual cooperation activities page 3 line 46).

\section{Data 7}

Ridho: It's okay. I don't bring my cellphone, save my number, 085373552566. (manuscript of mutual cooperation activities page 4 line 56).

\section{Data 8}

Rizki: No, come in please. Guest can not outside. (Manuscript for Maulid activities page 1 line 8).

\section{Data 9}

Ridho: I'll follow you go inside home. (the manuscript for Maulid activities page 1 line 10).

Data 10

Aldi: Jack, let me just bring it. (Manuscript for Maulid activities page 1 line 13).

\section{Data 11}

Jaki: It's okay, it's easy. (Manuscript for Maulid activities page 1 line 14).

\subsection{Maxim Award}

Data 12 
Ridho: Now it's good, the city of Panton Labu, the mosque is also good. Yesterday I saw right there. (manuscript of mutual cooperation activities page 1 line 18).

\section{Data 13}

Ridho: bro, you are good-looking, if you wait in the front, it will be better. (Manuscript for Maulid activities page 1 line 6).

\subsection{Maxim of Simplicity}

\section{Data 14}

Ridho: I don't dare to bang. Later, I was nervous about banging Rizki. (the manuscript for data entry activities page 1 line 4 ).

\subsection{Maxim Consultation}

\section{Data 15}

Ridho: Ow he is, who is his brother? (manuscript of mutual cooperation activities page 1 line 6).

\section{Data 16}

Ridho: Ow you are the grandson of Panton Labu huh? (manuscript of mutual cooperation activities page 1 line 8 ).

\section{Data 17}

Ridho: I live behind a fashion batik shop (manuscript for mutual cooperation activities page 1 line 12).

\section{Data 18}

Ridho: know, how come you know him? (manuscript of mutual cooperation activities page 1 line 14).

\section{Data 19}

Ridho: ow he once worked there, at a clothing store. (manuscript of mutual cooperation activities page 1 line 16).

\section{Data 20}

Ridho: Friends party place. (manuscript of mutual cooperation activities page 1 line 20).

\section{Data 21}

Ridho: he said last night he played, maybe soon he will come. (manuscript of mutual cooperation activities page 2 line 26).

\section{Data 22}

Ridho: He, because we made regulations. (manuscript of mutual cooperation activities page 2 line 28).

\section{Data 23}

Ridho: who we have never been in social work we won't care if they have an event or anything. (manuscript of mutual cooperation activities page 2 line 30 ).

\section{Data 24}

Ridho: close to the distroholic next to the terminal. (manuscript of mutual cooperation activities page 2 line 36 ).

\section{Data 25}

Ridho: Ridho. Whose name are you? (manuscript of mutual cooperation activities page 3 line 42).

\section{Data 26}


Ridho: He is every Friday. If the place where you live in the city of latitude is Sunday, is mutual cooperation right? (manuscript of mutual cooperation activities page 3 line 44).

\section{Data 27}

Ridho: Ada, is there a maulid in Panton pumpkin? (activity manuscript page 3 line 50)

\section{Data 28}

Ridho: We are next week. Come on, Wis! (manuscript of mutual cooperation activities page 3 line 52).

\subsection{Maxim of Sympathy}

\section{Data 29}

Ridho: He wis. If you want to be allowed next Friday, you will join in the work together like this too, so you can get along with this person quickly. (manuscript of mutual cooperation activities page 3 line 48).

\section{Discussion}

The results of research on language politeness among teenagers in Bukit Tempurung Village, Kota Kuala Simpang District, Aceh Tamiang District were found in six maxims. With the details, the maxim of wisdom is four (4) data, the maxim of generosity is as much as seven (7) data, the maximal award is two (2) data, the maxim of simplicity is one (1) data, the maximal agreement is fourteen (14 ) data, and the maximal conclusions are one (1) data. The discussion is on each data

\subsection{Maxim of Wisdom}

The wisdom of wisdom is a communication maxim that reduces one's own profit and maximizes the other party's profit in speaking activities. In this study the maxim of wisdom was found in 4 data, namely data 1, 2, 3 and 4 . The data can be proven and described in data 1 in the conversation quote "Ridho: You can bang, just join. (manuscript of mutual cooperation activities page 1 line 4) ". The politeness of the language above is a maxim of wisdom, clearly Ridho reduces his own profits and maximizes the profits of the researcher. Next, the maximum wisdom in data 2 "Ridho: Just come, sir. We wait. (manuscript of mutual cooperation activities page 3 line 54) ". In this quote Ridho reduces his own profits and maximizes the profits of the researcher.

Furthermore, data 3 is also still related to the maxim of wisdom in data 3 "Ridho: yes wis, I'll bring it later. (manuscript of mutual cooperation activities page 4 line 60) ". It clearly shows that Ridho is wise to help the researcher when delivering the message. While the maximal wisdom in data 4 "Ridho: Waalaikumsalam. Please enter wis. (manuscripts of maulid activities page 1 line 2) The politeness of the language above is the maxim of wisdom, where Ridho reduces his own profits and maximizes the profits of the researcher.

\subsection{Maxim Generosity}

Maxim is a generosity that is the maxim of generosity, which requires the speaker to respect others. This respect occurs if the participant can minimize profits for himself and maximize profits for others. In this study the generosity maxim was found in 7 data. Namely 
data $5,6,7,8,9,10$, and 11 . In data 5 there is a conversation "Rizki: Yes just join us. (manuscript of mutual cooperation activities page 1 line 10) ".

Next, Data 6 "Ridho: If you want to know this person later, tonight we will sit in the warkop if I want to work? so later you can know this person. (manuscript of mutual cooperation activities page 3 line 46) ". In this data it is very clear that Ridho's generosity when making other people happy makes his generosity.

Next, Data 7 "Ridho: it's okay, just copy it. I don't have a cellphone, 085373552566. (manuscript of mutual cooperation activities page 4 line 56) ". This data is also included in the maxim of generosity because it can be shared with others if others need help.

Next, Data 8 "Rizki: No, now only brother comes in. Cook guests outside. (Manuscript for Maulid activities page 1 line 8) ". It is clearly seen in this data that speakers respect others.

Next, Data 9 "Ridho: Yok wis I take it inside. (Manuscript for Maulid activities page 1 line 10) ". It is clearly seen in this data that speakers respect others.

Next, Data 10 "Aldi: Jack let me just lift it. (Manuscript for Maulid activities page 1 line 13) ". There is an explanation in this data that the speech participants can minimize profits for themselves and maximize profits for others. And then data 11 "Jaki: It's okay at this, it's easy. (Manuscript for Maulid activities page 1 line 14) ". The data is clearly visible which requires the participants to respect others, called the maxim of generosity (generosity).

\subsection{Maxim Award}

The maximum award is the maxim that makes people be considered polite when speaking always tries to give appreciation to other parties. In this study the award maxim was found in 2 data. Data 12 "Ridho: Now it's good, the city of Panton Labu, the mosque is also good. Yesterday I saw right there. (manuscript of mutual cooperation activities page 1 line 18). In this data, it is clear that speakers try to reward others.

Furthermore, Data 13 "Ridho: bro, you are good looking handsome, if you wait in the front, it will be better bg. (Manuscript for Maulid activities page 1 line 6). And in this data, it is also clear that the participants did not copy or ridicule others.

\subsection{Maxim of Simplicity}

Maxim's simplicity or maxim of humility is the maxim that expects speech participants to be humble by reducing praise to themselves. In this study the simplicity maxim found only 1 data. Namely data 14 "Ridho: I don't dare to bang. Later, I was nervous about banging Rizki. (Manuscript for Maulid activities page 1 line 4). Obviously, in this data the speech participants can be humble by reducing praise to themselves.

\subsection{Maxim Consultation}

The maxim of consensus is the maxim which requires that the speech participants can foster mutual compatibility in speaking activities. The maximum agreement that the researchers found in this study is that there are very many 14 data, namely: 15, 16, 17, 18, 19, 20, 21, 22, 23, 24, 25, 26, 27 and 28.

Data 15 "Ridho: Ow he is, Who is his brother? (manuscript of mutual cooperation activities page 1 line 6). This data clearly includes the maxim of consensus because speakers build mutual compatibility in speaking activities. 
Furthermore, Data 16 "Ridho: Ow you are his grandson from Panton Labu huh? (manuscript of mutual cooperation activities page 1 line 8 ). This data can also be classified into the maximal agreement because the listener quickly responds to the statement of the researcher when he tells him that granddaughter Halimah.

Furthermore, Data 17 "Ridho: I live behind a fashion batik shop (manuscript for mutual cooperation activities page 1 line 12). These data are compatible with each other responding to the inquiry from researchers towards adolescents while carrying out mutual cooperation activities.

Furthermore, Data 18 "Ridho: know, how come you know him? (manuscript of mutual cooperation activities page 1 line 14). This data is also classified into the maxims of agreement because Ridho immediately answers questions from researchers and immediately asks again the questions that concern the conversation and Ridho fosters mutual compatibility in speaking activities.

Furthermore, Data 19 "Ridho: ow he once worked there, at a clothing store. (manuscript of mutual cooperation activities page 1 line 16) ". This data is also classified into the maxims of agreement because Ridho immediately answers questions from researchers and immediately asks again the questions that concern the conversation and Ridho fosters mutual compatibility in speaking activities.

Furthermore, Data 20 "Ridho: Friends party place. (manuscript of mutual cooperation activities page 1 line 20) ". These data are compatible with each other responding to the inquiry from researchers towards adolescents while carrying out mutual cooperation activities.

Furthermore, Data 21 "Ridho: he said last night he stopped, maybe soon he will come. (manuscript of mutual cooperation activities page 2 line 26) ". This data clearly includes the maxim of consensus because speakers build mutual compatibility in speaking activities.

Furthermore, Data 22 "Ridho: He, because we made regulations. (manuscript of mutual cooperation activities page 2 line 28) ". Speech participants develop mutual compatibility when answering questions from researchers.

Furthermore, Data 23 "Ridho: we made who never was in social work we would not care if they had an event or anything. (manuscript of mutual cooperation activities page 2 line 30). Speech participants develop mutual compatibility when answering questions from researchers.

Next, Data 24 "Ridho: close to distroholic which is next to the terminal. (manuscript of mutual cooperation activities page 2 line 36). Speech participants develop mutual compatibility when answering questions from researchers.

Furthermore, Data 25 "Ridho: Ridho. Whose name are you? (manuscript of mutual cooperation activities page 3 line 42). Speech participants develop mutual compatibility when answering questions from researchers.

Furthermore, Data 26 "Ridho: He is every Friday. If the place where you live in the city of latitude is Sunday, is mutual cooperation right? (manuscript of data cooperation activities page 3 line 44). This data is also classified into the maxims of agreement because Ridho immediately answers questions from researchers and immediately asks again the questions that concern the conversation and Ridho fosters mutual compatibility in speaking activities. 
Furthermore, Data 27 "Ridho: Ada, is there a maulid in Panton pumpkin? (manuscript of mutual cooperation activities page 3 line 50). This data clearly includes the maxim of consensus because speakers build mutual compatibility in speaking activities. And Data 28 "Ridho: We are next week. Come on, Wis! (manuscript of mutual cooperation activities page 3 line 52). With these data, it is clearly included in the maxims of agreement because the partner can mutually foster compatibility in speaking activities, meaning that the village of the hillside village is not arrogant and can undergo good conversation.

\subsection{Maxim of Sympathy}

Maximum sympathy is the maxim that expects the speech participants to maximize sympathy between one party and the other. In this study the maximal conclusions were found in only 1 data. That is data data 29 "Ridho: He wis. If you want to be allowed next Friday, you will join in the work together like this too, so you can get along with this person quickly. (manuscript of mutual cooperation activities page 3 line 48). In this data clearly classified the maximal conclusions, because Ridho sympathized with his said opponent when the participants needed help, so that the newcomers got many new friends in the village of the hill shell.

\section{Conclusion}

Based on the results of research on "Analysis of politeness in the language of the youth of Kuala Simpang City, Aceh Tamiang Regency viewed from sociolinguistics". So the conclusion that can be taken is that politeness among adolescents in Bukit Tempurung Village, Kuala Simpang, Aceh Tamiang Regency is viewed from sociolinguistics. After the researchers conducted an analysis of the language politeness data that the authors analyzed for fifteen days, starting from 25-03-2018 s-d 04-08-2018. Twenty-nine (29) language politeness data, which are grouped into 6 maxims, namely: wisdom maxims of four (4) data, maximal generosity is as many as seven (7) data, the maximal award is two (2) data, maxim of simplicity is one (1) data, the maximal agreement is as many as fourteen (14) data, and the conclusion of conclusions is one (1) data. Based on the research data, the most dominant maxim used is the agreement maxim.

\section{References}

Chaer Abdul, Leonie Agustina. 2004. Sosiolinguistik Perkenalan Awal. Jakarta: PT. Rineka Cipta. Chaer Abdul. 2007. Linguistik Umum. Jakarta: PT. Rineka Cipta.

Chaer Abdul. 2010. Kesantunan Berbahasa. Jakarta: PT. Rineka Cipta.

Kridalaksana. 2001. Memahami Pragmatik. Jakarta: PT. Gramedia.

Markhamah. 2011. Analisis Kesalahan dan Kesantunan Berbahasa. Surakarta: Muhammadiyah University Press.

Moleong Lexy. 2010. Metodologi Penelitian Kualitatif. Bandung: PT. Remaja Rosdakarya.

Mukhtar Sam. 2001. Pragmatik. Jakarta: Universitas Terbuka

Rahardi Kunjana. 2005. Pragmatik Kesantunan Imperatif Bahasa Indonesia. Jakarta: Erlangga.

Sugiyono. 2008. Memahami Penelitian Kualitatif. Bandung: CV. Alfabeta.

Sugiyono. 2009. Metode Penelitian Pendidikan. Bandung: CV. Alfabeta.

Sumarsono. 2004. Sosiolinguistik. Yogyakarta: Pustaka Pelajar dan Sabda.

Tarigan Guntur. 2003. Pengajaran Gaya Bahasa. Bandung: Angkasa.

Tarigan Guntur. 2009. Pengajaran Pragmatik. Bandung: Angkasa. 